UDC 811.111.81'44

DOI https://doi.org/10.32841/2409-1154.2021.48-1.26

Kulish A. R., Postgraduate Student Borys Grinchenko Kyiv University, Senior Lecturer at the Department of Philology, Translation and Strategic Communication National Academy of the National Guard of Ukraine

\title{
COMMUNICATIVE STRATEGIES OF THE SPEECH PERSONALITY (ON THE MATERIAL OF SPEECH BEHAVIOUR OF SHERLOCK HOLMES)
}

Summary. The paper discusses the speech personality of Sherlock Holmes in the aspect of communicative linguistics. The aim of the paper is to identify linguistic features of speech behaviour of Sherlock Holmes. In order to achieve the aim there has been requested the classification of communicative strategies of $\mathrm{O}$. Issers that is based on functional significance. This classification assumes the following communicative strategies: strategy of discrediting and subjugation, pragmatic, dialogue and rhetorical strategies. Every communicative strategy is accompanied by the use of a certain speech move with intention to achieve a communicative goal. Speech moves of Sherlock Holmes are filled with certain linguistic features, namely, the lexical and grammatical linguistic layers. To achieve the aim, the following methods were used: method of analysis was applied to study the theoretical basis of the concepts of speech personality in the area of communicative linguistics; method of synthesis was used to summarize the main principles and conclusions of the paper; descriptive and structural methods made it possible to characterize the linguistic features of Sherlock Holmes' speech taking into account the communicative strategies; the method of conversational analysis was used to study the strategic linguistic features of the construction of the discourse. The research shows that Sherlock Holmes operates such linguistic features in his speech behaviour: the use of negatively marked nouns like "stupid", "idiot" in order to undermine the authority; imperative sentences and imperative phrasal verbs such as "get out", "go away", "shut up", imperative verbs "don't", "stop" to establish his own authority; exclamatory sentences and adverbs such as "neat", "brilliant", "fun" to attract attention of his interlocutor; adverbs as "obviously", "exactly", idiom "of course" to demonstrate his superiority and power in communication.

Key words: speech personality, speech behaviour, speech move, communicative linguistics, linguistic features, communicative strategies.

Introduction. The cognitive paradigm that prevails in linguistics at the present stage is based on the principles of anthropocentrism, i.e. human with all his her mental processes is the starting point of all linguistic studies. The study of the anthropocentric paradigm "human in language" contributed to the rapid development of a new branch of science - linguistic personology, which studies the issues on the linguistic personality, in particular the speech personality of both the individual and the whole nation.

Every speech personality in his her speech behaviour operates with different communicative strategies. In modern linguistics, communicative strategy is regarded as a set of certain speech moves aimed at achieving a communicative goal by choosing effective speech moves, as well as their flexible modification in a particular situation. The peculiarity of communicative strategies is their flexibility and dynamics in the process of communication; speech behaviour undergoes constant adjustments depending on the discourse, which is constantly supplemented and changed.

The aim of the paper is to define the main linguistic features of Sherlock Holmes through the analysis of his speech behaviour taking into account the communicative strategies. Despite the interest of scientists in speech personality, there is a noticeable lag in the creation of speech portraits of TV characters in the aspect of communicative linguistics, thereby the relevance of this paper is marked.

The study of speech personality in the aspect of communicative linguistics is carried out by studying the psychological attitudes and level of communicative competence of real representatives of a particular nation with the whole spectrum of speech manifestation. On the contrary, when it comes to a TV character or a protagonist of some work of art, the spectrum of speech manifestation is narrowed and restricted to a certain communicative situation (discourse). This explains the problematic of the paper because the material of our research is the British TV series "Sherlock" [1;2].

To achieve the aim, the following methods were used: method of analysis was applied to study the theoretical basis of the concepts of speech personality in the area of communicative linguistics; method of synthesis was used to summarize the main principles and conclusions of the paper; descriptive and structural methods made it possible to characterize the linguistic features of Sherlock Holmes' speech taking into account the communicative strategies; the method of conversational analysis was used to study the strategic linguistic features of the construction of the discourse.

Theoretical Background. The tradition of studying the speech personality is originated in the works of V. Humboldt, V. Vinogradov, Yu. Karaulov, O. Leontiev, G. Bogin, and others. The ways of formation of speech personality are laid down in a number of concepts of the theory of language personality by Yu. Prokhorov, V. Krasnykh, L. Klobukova, etc. Yu. Prokhorov [3] suggests that speech personality is revealed in a specific communication situation, and in order to achieve a positive result of this communication, all components of the speech personality are realized. V. Krasnykh [4] suggests to consider the speech personality, focusing on the speech activity of the language personality.

The issue of communication strategies is covered in the works of A. Bielova, Dzh. Humperz, T.A. van Dijk, S. Derien, 
O. Dmytruk, O. Ilchenko, O. Issers, W. Kintsch, H. Pocheptsov, etc. Communicative strategies and tactics are reflected in the research of the following linguists: N. Vasylenko, M. Vulfson, N. Honcharova, Kh. Hruber, N. Korobova, P. Robinson, I. Shkitska, O. Iashenkova.

Main results. Before analyzing the speech personality of Sherlock Holmes and his communicative strategies, we need to consider the classification of communicative strategies. Currently, common typology of communicative strategies have not been yet created because of the variety of communicative discourse [5]. The classification of communicative strategies of T.A. van Dijk and W. Kintsch [6] is considered to be the basic one. Researchers distinguish contextual, speech, semantic, syntactic, schematic, textual strategies of communication. Others distinguish communicative and semantic; cooperative and non-cooperative strategies of communication.

T. Tolmachova [7] offers a methodological typology of communicative strategies based on speech acts, grouped on the principle of similarity of communicative functions (exchange of information, assessment or comments, expression of emotions, motivation and regulation of relations, attention support). Accordingly, there are following communication strategies: informative, evaluative and influential, emotional and influential, regulatory and incentive, conventional.

In our research we will use the classification of communicative strategies of 0 . Issers [8] that is based on functional significance. The researcher identifies the main and supplemental communicative strategies. The main strategies, whether cognitive or semantic, are primarily aimed at influencing the interlocutor to change histher perceptions of the world, value system, behaviour, etc. (e. g. strategy of discrediting, subjugation). The supplemental strategies contribute to the effective organization of dialogue and can be divided into:

1. Pragmatic (communicative-situational) strategies that are focused on the speaker's self-expression and the choice of the optimal speech act, which best corresponds to communicative situation (e. g. to create an image, adjust emotional mood, etc.).

2. Dialogue (conversation) strategies, the purpose of which is to control the topic of communication, initiative in dialogue, etc.

3. Rhetorical strategies, which involves the use of various techniques of public speaking to increase the impact on the interlocutor (e.g. the strategy of attracting attention, dramatization of the presentation, etc.).

The communicative strategy of discrediting means the deliberate speech moves aimed at undermining the authority, image and trust in someone, belittling his her dignity and authority with a help of certain linguistic features. Let's analyze the following examples of Sherlock Holmes' speech behaviour:

"I dislike being outnumbered. It makes for too much stupid in the room".

"Your mind: it's so placid, straightforward, barely used. Mine's like an engine, racing out of control; a rocket tearing itself to pieces trapped on the launch pad".

"Miss Mackenzie, you're in charge of pupil welfare, yet you left this place wide open last night. What are you: an idiot, a drunk or a criminal?"

"Well, anybody who wears a hat as stupid as this isn't in the habit of hanging around other people, is he?"

"SHERLOCK: Brilliant, Anderson.

ANDERSON: Really?
SHERLOCK: Yes. Brilliant impression of an idiot”.

"SHERLOCK: I don't care what people think.

JOHN: You'd care if they thought you were stupid, or wrong.

SHERLOCK: No, that would just make them stupid or wrong" [1;2].

Based on the analysis of the Sherlock Holmes' speech behaviour given above, the use of negatively marked nouns like "stupid", "idiot" and adjectives "wrong", "straightforward", "placid" demonstrates the intention of Sherlock Holmes to point out the ignorance of society and undermining the authority with a help of communicative strategy of discrediting.

The communicative strategy of subjugation denotes the intention of speech personality to bring to heel someone using certain linguistic means. Such intention is manifested in the Sherlock Holmes' speech behaviour:

"Lestrade. We've had a break-in at Baker Street. Send your least irritating officers and an ambulance".

"Anderson, don't talk out loud. You lower the I.Q. of the whole street".

"Shut up, everybody, shut up! Don't move, don't speak, don't breathe".

"Very nice, yes, good. Get out".

"MRS HUDSON: Isn't the doorbell working? Your taxi's here.

SHERLOCK: I didn't order a taxi. Go away".

"SHERLOCK: Might need some food.

MRS HUDSON: I'm your landlady, dear, not your housekeeper.

SHERLOCK: Something cold will do. John, have a cup of tea, make yourself at home. Don't wait up!"

"SHERLOCK: Scuse me.

JOHN: What-what's up, Sherlock?

SHERLOCK : I said excuse me" [1;2].

Sherlock Holmes uses imperative sentences with intention to establish his own authority; applying of imperative phrasal verbs such as "get out", "go away", "shut up", imperative verbs "don't", "stop" and adjective "least irritating" encourage Sherlock Holmes' interlocutors to obey his orders and prohibitions. The use of the imperative mood in Sherlock Holmes' speech indicates his dominance in communication.

The dialogue strategies can be carried out at different levels at which participants are influenced or influence others with a help of certain linguistic means. Dialogue strategies issues are those speech moves regarding the topics to be addressed in the dialogue. These are issues in which Sherlock Holmes has a point of view and wants to influence the interlocutor's attitude. Sherlock Holmes in his speech operates with dialogue strategies in order to change, avoid or cease the topic of conversation.

"No, sorry, Doctor Mortimer wins. Childhood trauma masked by an invented memory. Boring! Goodbye, Mr. Knight. Thank you for smoking".

"HENRY: It's an amazing place. It's like nowhere else. It's sort of $<\ldots>$ bleak but beautiful.

SHERLOCK: Mmm, not interested. Move on".

"JOHN: So, she's alive then. How are we feeling about that?

SHERLOCK: Happy New Year, John".

"JOHN: Okay, this is too much. We need to be more careful.

SHERLOCK: It's got flaps $<\ldots$.. > ear flaps. It's an ear hat, John".

"SHERLOCK: Four people are dead. There isn't time to talk to the police.

JOHN: So why are you talking to me?

SHERLOCK: Mrs Hudson took my skull” [1;2]. 
To change the topic of dialogue, Sherlock Holmes resorts to infraction of the logical development of conversation. This is an indicator of Sherlock Holmes's dominance over his interlocutor. Here Sherlock Holmes uses imperative sentences with intention to influence his interlocutor and convince him ไher.

The rhetorical strategy of attracting attention is aimed to make interlocutor notice someone or something using definite speech moves and linguistic features. Sherlock Holmes operates method of the "exclamation phrase" and raising voice in his speech with intention to draw attention. Such intention is manifested in the Sherlock Holmes' speech behaviour in the situation of detective investigation:

"The hungrier they got, the more they ate $<\ldots>$ the faster they died. (He grins.) Neat".

"Twenty year old disappearance; a monstrous hound? I wouldn't miss this for the world!".

"Murder weapon and scene of the crime all at once. (He laughs with delight.) Oh, this case, Henry! Thank you. It's been brilliant".

"Bit mean, springing it on you like that, I know. Could have given you a heart attack, probably still will. But in my defence, it was very funny".

"It's murder, all of them. I don't know how, but they're not suicides, they're killings - serial killings. We've got ourselves a serial killer. I love those. There's always something to look forward to".

"SHERLOCK: Yeah, well, this is more fun.

JOHN: Fun? There's a woman lying dead" [1;2].

In the given examples of Sherlock Holmes' speech behaviour we trace a sharp and ill-considered reaction to various crimes (serial murders, suicides, mysterious disappearances, etc.) which is denoted by the exclamatory sentences and adverbs such as "neat", "brilliant", "fun" in order to attract attention of his interlocutor or others.

Dramatization of the presentation is achieved by fixing the facts, phenomena, events, behind which there is some danger for a personality or the opportunity to get some pleasure, to get out of trouble, to find glory and power. Sherlock Holmes' speech is characterized by markers of confidence, the most popular of which is an adverb "obviously". The mentioned word is a modern interpretation of the already set expression "elementary":

"You said trained at Bart's, so Army doctor - obvious".

"Of course she's not. She's from out of town, though. Intended to stay in London for one night $<\ldots>$ before returning home to Cardiff. So far, so obvious".

"Yes, obviously. Oh, perhaps I should mention: I didn't kill her".

"Oh, well, perhaps he shouldn't have done. He was obviously just trying to show off".

"SHERLOCK: I have high hopes for you, Inspector. A glittering career.

DIMMOCK: I go where you point me.

SHERLOCK: Exactly".

"You've got a psychosomatic limp - of course you've got a therapist".

"I know it wasn't. The same way that I know the victim was an excellent sportsman recently returned from foreign travel and that the photographs I'm looking for are in this room" " $[1 ; 2]$.

Sherlock Holmes uses such adverbs as "obviously", "exactly", idiom "of course" and simple sentences "I know", "I think" with the intention to demonstrate his superiority and power both in communication and intellectual development.
Conclusions. In this article we have outlined and described Sherlock Holmes as the speech personality in the aspect of communicative linguistics. The main linguistic features of Sherlock Holmes' speech behaviour were analyzed taking into account the communicative strategies. In his speech, Sherlock Holmes often makes use of such communicative strategies: strategy of discrediting and subjugation, dialogue and rhetorical strategies. Depending on the chosen strategy and communicative discourse, Sherlock Holmes operates such linguistic features in his speech behaviour: the use of negatively marked nouns like "stupid", "idiot" in order to undermine the authority; imperative sentences and imperative phrasal verbs such as "get out", "go away", "shut up", imperative verbs "don't", "stop" to establish his own authority; exclamatory sentences and adverbs such as "neat", "brilliant", "fun" to attract attention of his interlocutor; adverbs as "obviously", "exactly", idiom "of course" to demonstrate his superiority and power in communication. The prospect of further study of the speech personality of Sherlock Holmes will be considered in terms of communicative competence. The level of communicative competence of Sherlock Holmes will be studied on the base of four communicative competence areas: linguistic, sociolinguistic, discourse and strategic.

\section{References:}

1. Sherlock transcripts (1-3 seasons). Forever dreaming. Retrieved from https://transcripts.foreverdreaming.org/viewforum.php?f=51 (access date: $25-30.03 .21)$.

2. Translation in context. Sherlock in the original version with English subtitles. URL: https://www.opensubtitles.org/en/ssearch/ sublanguageid-eng/ idmovi- 59571 (access date: 25-30.03.21).

3. Прохоров Ю. Действительность. Текст. Дискурс : учебное пособие. Москва : Флинта ; Наука, 2004. 224 с.

4. Красных В. «Свой» среди «чужих»: миф или реальность? Москва : Гнозис, 2003. 375 c.

5. Белова А. Комунікативні стратегії і тактики: проблеми систематики. Мовні і концептуальні картини світу : збірник наукових праць. Київ : КНУ імені Тараса Шевченка, 2004. С. 11-16.

6. Dijk Teun A. van, Kintsch Walter. Strategies of Discourse Comprehension. New York : Academic Press, 1983. 389 p.

7. Толмачева Т. К вопросу о типологии коммуникативных стратегий. Горный Алтай: проблемы билингвизма в поликульутрном пространстве : сборник научных трудов. ГорноАлтайск : РИО ГАГУ, 2006. C. $159-162$.

8. Иссерс О. Коммуникативные стратегии и тактики русской речи 5-е изд. Москва : Изд-во ЛКИ, 2008. 288 с.

Куліш А. Комунікативні стратегії мовленнсвої особистості (на матеріалі мовленнсвої поведінки Шерлока Холмса)

Анотація. У статті розглядається мовленнєва особистість Шерлока Холмса в аспекті комунікативної лінгвістики. Метою статті є визначення мовних особливостей Шерлока Холмса шляхом аналізу його мовленнєвої поведінки з урахуванням комунікативних стратегій. Для досягнення поставленої мети було запропоновано класифікацію комунікативних стратегій О. Іссерс, яка базується на функціональному значенні. Класифікація включає такі комунікативні стратегії, як стратегія дискредитації та підкорення, прагматичні, діалогові та риторичні стратегії. Кожна комунікативна стратегія супроводжується використанням певних мовленнєвих ходів із наміром досягти комунікативної мети. Мовленнєві ходи Шерлока Холмса наповнені 
деякими мовними особливостями, а саме лексичними та граматичним, що були дослідженні. Для досягнення мети було використано такі методи: метод аналізу для дослідження теоретичних основ концепції мовленнєвої особистості в галузі комунікативної лінгвістики; метод синтезу для узагальнення основних результатів та висновків статті; описовий та структурний методи для характеристики мовних особливостей Шерлока Холмса з урахуванням комунікативних стратегій; метод конверсаційного аналізу був використаний для вивчення стратегічних і лінгвістичних особливостей побудови дискурсу. У результаті дослідження нами було встановлено такі лексико-граматичні особливості мовленнєвої поведінки Шерлока Холмса: негативно марковані іменники "stupid", "idiot”, щоб дискредитувати співрозмовника; наказові речення та наказові фразеологічні дієслова "get out", "go away", "shut up", наказові дієслова “don't", "stop" з метою виявлення власного авторитету під час розмови; окличні речення та прислівники на кшталт “neat", “brilliant”, “fun”, щоб привернути увагу свого співрозмовника; прислівники "obviously", “ехactly", ідіому "of course" для демонстрації власної переваги під час комунікації.

Ключові слова: мовленнєва особистість, мовленнєва поведінка, мовленнсвий хід, комунікативна лінгвістика, мовні особливості, комунікативні стратегії. 